\title{
STAPHYLOCOCCUS AUREUS FROM READY-TO-EAT FOOD AS A SOURCE OF MULTIPLE ANTIBIOTIC RESISTANCE GENES
}

\author{
Wioleta Chajęcka-Wierzchowska, ${ }^{1}$ Anna Zadernowska, ${ }^{2}$ Lucja Laniewska-Trokenheim
}

\begin{abstract}
The emergence of antibiotic-resistant strains of S. aureus such as methicillin-resistant S. aureus (MRSA) is a worldwide problem. Ready-to-eat (RTE) food which does not need thermal processing before consumption could be a vehicle for the spread of antibiotic-resistant microorganisms. The present study evaluated the molecular genetic characteristics (RAPD) and pheno- and genotypical antimicrobial resistance profile of S. aureus isolated from 75 RTE food samples (sushi, hamburgers, salads). All of the isolates $(\mathrm{n}=32)$ were resistant to at least one class of antibiotic tested of which $75 \%$ strains were classified as multidrug resistant. Most of the isolates were resistant to cefoxitin $(87,5 \%)$ followed by clindamycin $(78,1 \%)$, tigecycline and quinupristin/dalfopristin $(53,1 \%)$. All methicillin resistant staphylococci harbored $m e c \mathrm{~A}$ gene. Among tetracycline resistance isolates all of them harbored at least one gene: $\operatorname{tet}(\mathrm{M}), \operatorname{tet}(\mathrm{L})$ and/or $\operatorname{tet}(\mathrm{K})$ and $78,9 \%$ of them were positive for the Tn916/Tn1545-like integrase family gene. Our results indicated that retail RTE food could be considered an important route for transmission of antibiotic resistant staphylococci harboring multiple antibiotic resistance genes.
\end{abstract}

UDC Classification: 614; DOI: http://dx.doi.org/10.12955/cbup.v5.1079

Keywords: antibiotic resistance, Staphylococcus aureus, antibiotic resistance genes, MRSA

\section{Introduction}

Staphylococcus aureus is one of the leading etiologic agents of hospital infections (Le Loir et al., 2003). It is known to cause a number of pathological conditions in humans and animals like bacteremia, urinary system infections, systemic diseases, osteomyelitis (Lina et al., 1999; Hageman et al., 2006). Toxins produced by $S$. aureus are one of the most frequent causes of bacterial food poisonings (Hennekinne et al., 2012). Foodstuff contamination may result from poor hygiene during production processes or the retail and storage of food. The pathogenic nature of $S$. aureus is related to the high genotypic and phenotypic heterogeneity of its strains. This results mainly from the abilities of staphylococci to exchange genetic material through mobile genetic elements.

Growing antibiotic resistance in $S$. aureus strains is a worldwide problem. The most worrying are strains resistant to methicillin (Methicillin-resistant Staphylococcus aureus - MRSA). The presence of antibiotic resistant strains among food derived microorganisms suggests that it may play a much more important role in transferring the antibiotic resistance encoding genes than previously thought (Chajęcka-Wierzchowska et al., 2016). Antibiotics are used for prophylactic purposes in swine, cattle, rabbit and poultry production as well as in vegetable and fruit cultivation and beekeeping (Ding and $\mathrm{He}, 2010$ ) and, thus, the meat of farm animals, fruit, vegetables and water may be a source of resistant strains. Food and feed safety is essential, and the presence of MRSA in the food chain may contribute to the increasing dissemination of MRSA worldwide (Oniciuc et al., 2017). The multi-drug resistant $S$. aureus strains may have an increased ability to spread. This does not only provide therapeutic challenges for clinicians but may be very detrimental to human health. The study was designed to determine the occurrence of $S$. aureus and MRSA strains in ready-to-eat food products as sushi, salads, and hamburgers in Poland. Moreover, the presence of genes which encode resistance to methicillin and tetracycline's was investigated.

\section{Materials and methods}

\subsection{Isolation and biochemical identification of the strains}

Staphylococci were isolated from samples obtained from sushi, hamburgers and salads purchases in fast-food bars and restaurants. Totally, 75 ready-to-eat samples were collected. These consisted of 25 sushi samples, 25 hamburgers and 25 salads. Samples were immediately transported to the laboratory under refrigerated conditions. All microbiological analyses were performed within the same day. Food samples (10 g) were homogenized in $90 \mathrm{ml}$ buffered peptone water (Merck, Germany), incubated overnight at $37^{\circ} \mathrm{C}$ and streaked on selective plates containing Mannitol Salt Phenol-red Agar (Merck,

\footnotetext{
${ }^{1}$ Chair of Industrial and Food Microbiology, Unversity of Warmia and Mazury in Olsztyn, wioleta.chajecka@uwm.edu.pl

${ }^{2}$ Chair of Industrial and Food Microbiology, Unversity of Warmia and Mazury in Olsztyn, anna.zadernowska@uwm.edu.pl

${ }^{3}$ Chair of Industrial and Food Microbiology, Unversity of Warmia and Mazury in Olsztyn, lucja.laniewskatrokenheim@uwm.edu.pl
} 
Germany). Mannitol (+) colonies were differentiated into coagulase-positive and coagulase-negative with a test detecting the production of a clumping factor $(\mathrm{CF})$ and production of coagulase on the RPF medium (Biomerieux) with rabbit blood plasma and fibrinogen. Isolates were Gram-stained using standard techniques. Gram positive, coagulase positive bacteria were presumptively identified as staphylococci and were selected for further biochemical identification. Prior to analysis, isolates were stored in Microbank at $-80^{\circ} \mathrm{C}$ (Biocorp, Poland).

\subsection{Bacterial strains and DNA extraction}

For DNA extraction bacterial strains were cultivated on Brain Heart Infusion Broth with agar (BHI, Merck, Germany) at $37^{\circ} \mathrm{C}$. Colony were suspended in TE buffer and lysed by Lizostaphin enzyme $(0,6 \mathrm{mg} / \mathrm{ml})$. Total Genomic DNA of isolated and reference strains was extracted using the Genomic Mini DNA Purification Kit (A\&A Biotechnology) according to the manufacturer's instructions.

\subsection{Molecular identification of isolates to the genus level}

RAPD-PCR reactions were performed with primer M13 according to protocol published by Andrighetto et al., (1996). For the identification of isolates to the genus level, part of the 16S rRNA Staphylococcus gene was amplified according to Morot-Bizot et al. (2004) Amplification was carried out in a Kyratec Super Cycler Trinity Triple Zone (Nippon Genetics Europe) PCR reaction mixture were analyzed by electrophoresis through a $2 \%$ high resolution agarose gel (Promega) in $1 \mathrm{x}$ TBE buffer $\mathrm{pH} 8,3$. The sizes of the amplification products were estimated by comparison with a 100-bp molecular size ladder (Thermo Scientific, Fermentas). Gels were stained with ethidium bromide. Images of the gels were visualized using the system for the documentation and analysis of fluorescently stained gels G-BOX F3 (Syngene) and analyzed using the program Gene Tools (Syngene). Each profile was visually compared with those obtained from the S. aureus ATCC $^{\circledR} 25923$ reference strain.

\subsection{Antimicrobial susceptibility test}

Antimicrobial susceptibility testing was performed on Mueller-Hinton agar (Biomérieux) using the disk diffusion method. Isolates were tested for their susceptibility to erythromycin $(\mathrm{E}, 15 \mu \mathrm{g})$,

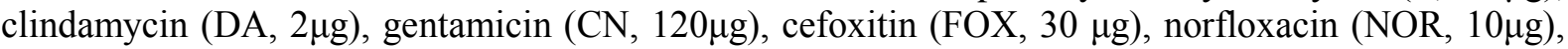

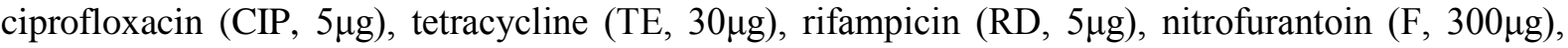

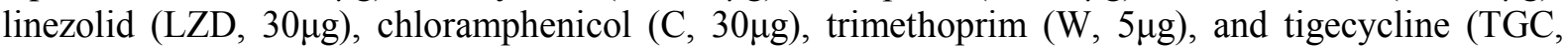

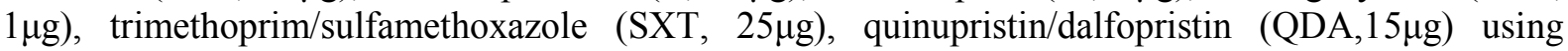
antimicrobial disks (Oxoid). Plates were incubated at $37^{\circ} \mathrm{C}$ for $20-24 \mathrm{~h}$ and results were interpreted according to the Clinical and Laboratory Standard Institute document M100-S20.

Table 1. Oligonucleotides used in PCR reactions.

\begin{tabular}{|c|c|c|c|}
\hline Primer & Primer sequence $\left(5^{\prime} \rightarrow 3^{\prime}\right)$ & \begin{tabular}{|l|} 
Amplicon \\
size (bp) \\
\end{tabular} & Source \\
\hline \multirow{2}{*}{ Staphylococcus spp. } & TIACCATTTCAGTACCTTCTGGTAA & \multirow{2}{*}{370} & \multirow{4}{*}{$\begin{array}{l}\text { Morot-Bizot, } \\
2005\end{array}$} \\
\hline & GGCCGTGTTGAACGTGGTCAAATCA & & \\
\hline \multirow{2}{*}{ S. aureus } & CGTAATGAGATTTCAGTAGATAATACAACA & \multirow{2}{*}{107} & \\
\hline & AATCTTTGTCGGTACACGATATTCTTCACG & & \\
\hline \multirow{2}{*}{ mecA } & AAAATCGATGGTAAAGGTTGGC & \multirow{2}{*}{533} & \multirow{2}{*}{ Barski, 1996} \\
\hline & AGTTCTGGCACTACCGGATTTGC & & \\
\hline \multirow{2}{*}{$\operatorname{tet}(\mathrm{L})$} & TGGTGGAATGATAGCCCATT & \multirow{2}{*}{229} & \multirow{4}{*}{ Rizzotti, 2005} \\
\hline & CAGGAATGACAGCACGCTAA & & \\
\hline \multirow{2}{*}{$\operatorname{tet}(\mathrm{M})$} & GTGGACAAAGGTACAACGAG & \multirow{2}{*}{406} & \\
\hline & CGGTAAAGT TCGTCACACAC & & \\
\hline \multirow{2}{*}{$\operatorname{tet}(\mathrm{K})$} & TTATGGTGGTTGTAGCTAGAAA & \multirow{2}{*}{348} & \multirow{2}{*}{ Gevers, 2003} \\
\hline & AAAGGGTTAGAAACTCTTGAAA & & \\
\hline \multirow{2}{*}{ int $(\operatorname{Tn} 916 / \operatorname{Tn} 1545)$} & GCGTGATTGTATCTCACT & \multirow{2}{*}{1046} & \multirow{2}{*}{$\begin{array}{l}\text { Macovei and } \\
\text { Zurek, } 2006\end{array}$} \\
\hline & GACGCTCCTGTTGCTTCT & & \\
\hline
\end{tabular}

\subsection{PCR detection of antimicrobial resistance genes}

All the strains phenotypically resistant to at least one antibiotic were examined for the presence of the resistance genes. Polymerase chain reaction for detection of genes mecA (533 bp) were carried out (Table 1). Amplification cycles for this two genes were done according to Barski et al. (1996). The 
tetracycline efflux gene tet $(\mathrm{K})$ amplification was performed according to Gevers et al. (2003). PCR detection of resistance to tetracyclines - tet $(\mathrm{M}), \operatorname{tet}(\mathrm{L})$ was determined using the specific primers and the conditions reported by Rizzotti et al. (2005). For all the tet(M)-positive isolates the presence of conjugative transposons of the $\operatorname{Tn} 916-\operatorname{Tn} 1545$ family was determined by using primers targeting the integrase gene int according to Macovei and Zurek (2006).

The amplicons were evaluated by $1,5 \%$ agarose gel electrophoresis followed by staining with ethidium bromide $(0.5 \mathrm{mg} / \mathrm{mL})$. Images of the gels were visualized using the system for the documentation and analysis of fluorescently stained gels G-BOX F3 (Syngene) and analyzed using the program Gene Tools (Syngene).

Results and discussion

The present study evaluated the molecular genetic characteristics (RAPD) and pheno- and genotypical antimicrobial resistance profile of $32 \mathrm{~S}$. aureus strains isolated from 75 RTE food samples (sushi, hamburgers, salads) (Figure 1).

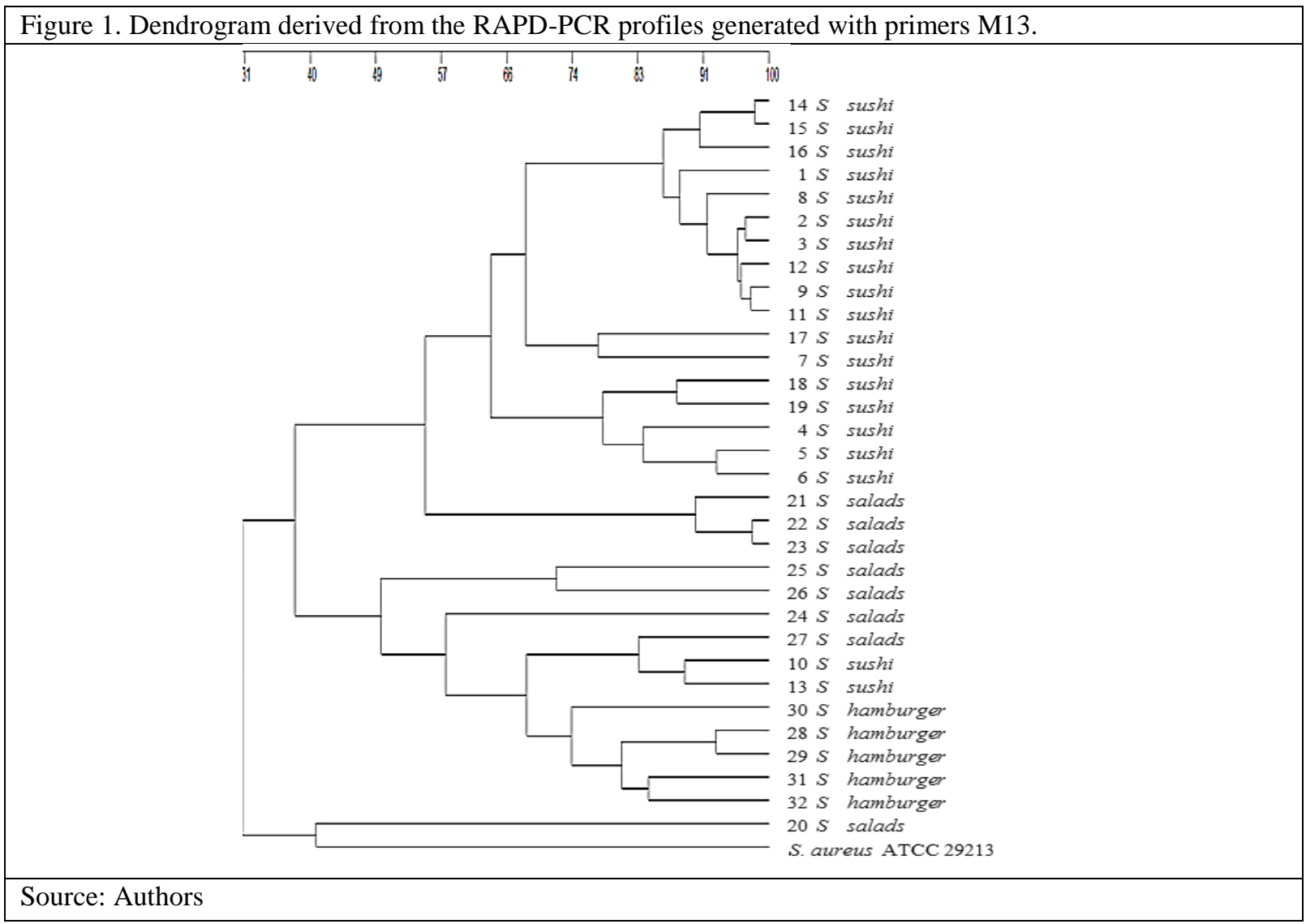

All staphylococcal isolates were examined for their susceptibility to 15 antibiotics. The data obtained from the disc diffusion testing are summarized in Table 2 . The overall percentages of antimicrobial resistant isolates were: $87,5 \%$ to cefoxitin, $78,1 \%$ to clindamycin, $53,1 \%$ to tigecycline and quinupristin/dalfopristin, $46,9 \%$ to tetracycline, $31,2 \%$ to rifampicin and gentamycin; $12,5 \%$ to trimetoprim/sulfametoxasol and nitrofurantoin; $9,4 \%$ to erythromycin and trimethoprim and $6,3 \%$ to ciprofloxacin and linezolid. All of the investigated strains $(n=32)$ were resistant to at least one class of antibiotic of which 24 strains were classified as multidrug resistant -MDR (resistant to three or more classes of antibiotics). Most MDR strains ( $n=11)$ revealed simultaneous resistance to 4 classes of antibiotics, followed by 5 strains to 6 classes; 4 strains to 5 classes; 3 strains to 3 classes. One of the examined strains revealed simultaneous resistance to antibiotics of 7 various classes (Table 2). All MDR strains $(n=24 ; 100 \%)$ were resistant to cefoxitin (FOX) and the majority of them $(n=20 ; 83,3 \%)$ were resistant to clindamycin (DA), 16 MDR strains $(66,7 \%)$ were resistant to quinupristin/dalfopristin, 14 of them $(58,3 \%)$ to tigecycline and 13 MRD strains $(54,1 \%)$ were resistant to tetracycline (Table 2). 
Table 2. Phenotypic and genotypic characterization of the S. aureus strains

\begin{tabular}{|c|c|c|c|c|c|c|c|}
\hline Strain number & \multirow{2}{*}{$\begin{array}{r}\text { Source } \\
\text { sushi } \\
\end{array}$} & \multicolumn{4}{|c|}{ Antibiotic resistance genes } & \multirow{2}{*}{$\begin{array}{l}\begin{array}{l}\text { Inte- } \\
\text { grase }\end{array} \\
- \\
\end{array}$} & \multirow{2}{*}{\begin{tabular}{|l} 
Antibiotic resistance phenotype \\
E, DA
\end{tabular}} \\
\hline 1 S. aureus & & - & - & - & - & & \\
\hline 2 S. aureus & sushi & $m e c(\mathrm{~A})$ & $\operatorname{tet}(\mathrm{L})$ & $\operatorname{tet}(\mathrm{M})$ & - & int & FOX, TE, E \\
\hline 3 S. aureus & sushi & $m e c(\mathrm{~A})$ & $\operatorname{tet}(\mathrm{L})$ & $\operatorname{tet}(\mathrm{M})$ & - & int & FOX, TGC, TE \\
\hline 4 S. aureus & sushi & $m e c(\mathrm{~A})$ & - & - & - & - & TGC, QD \\
\hline 5 S. aureus & sushi & $m e c(\mathrm{~A})$ & $\operatorname{tet}(\mathrm{L})$ & $\operatorname{tet}(\mathrm{M})$ & - & - & DA, FOX, TE, QD \\
\hline 6 S. aureus & sushi & $m e c(\mathrm{~A})$ & - & $\operatorname{tet}(\mathrm{M})$ & - & int & DA, FOX, TE, CN, QD \\
\hline $7 \quad$ S. aureus & sushi & $m e c(\mathrm{~A})$ & - & - & - & - & DA, FOX, RD, QD \\
\hline 8 S. aureus & sushi & - & - & - & - & - & DA \\
\hline 9 S. aureus & sushi & - & $\operatorname{tet}(\mathrm{L})$ & $\operatorname{tet}(\mathrm{M})$ & - & int & DA, FOX, TGC, TE, RD, CN, QD \\
\hline 10 S. aureus & sushi & $m e c(\mathrm{~A})$ & - & $\operatorname{tet}(\mathrm{M})$ & - & - & DA, FOX, TGC, SXT, RD, QD \\
\hline 11 S. aureus & sushi & $m e c(\mathrm{~A})$ & - & $\operatorname{tet}(\mathrm{M})$ & - & int & DA, FOX, TGC, TE, CN, QD \\
\hline 12 S. aureus & sushi & $m e c(\mathrm{~A})$ & $\operatorname{tet}(\mathrm{L})$ & $\operatorname{tet}(\mathrm{M})$ & - & int & DA, FOX, TGC, TE, RD, QD \\
\hline 13 S. aureus & sushi & $m e c(\mathrm{~A})$ & - & - & - & - & $\mathrm{DA}, \mathrm{FOX}, \mathrm{RD}, \mathrm{QD}$ \\
\hline 14 S. aureus & sushi & $m e c(\mathrm{~A})$ & $\operatorname{tet}(\mathrm{L})$ & $\operatorname{tet}(\mathrm{M})$ & - & int & DA, FOX, TGC, CIP, RD, CN, QD \\
\hline 15 S. aureus & sushi & $m e c(\mathrm{~A})$ & $\operatorname{tet}(\mathrm{L})$ & $\operatorname{tet}(\mathrm{M})$ & $\operatorname{tet}(\mathrm{K})$ & int & DA, FOX, TGC, TE, RD, CN, QD \\
\hline 16 S. aureus & sushi & $m e c(\mathrm{~A})$ & $\operatorname{tet}(\mathrm{L})$ & $\operatorname{tet}(\mathrm{M})$ & - & - & DA, FOX, TGC, TE, RD, CN, QD \\
\hline 17 S. aureus & sushi & $m e c(\mathrm{~A})$ & - & - & - & - & DA, FOX, TGC, TE, QD \\
\hline 18 S. aureus & sushi & $m e c(\mathrm{~A})$ & $\operatorname{tet}(\mathrm{L})$ & $\operatorname{tet}(\mathrm{M})$ & $\operatorname{tet}(\mathrm{K})$ & int & DA, FOX, W, TE, SXT, CN, QD \\
\hline 19 S. aureus & sushi & $m e c(\mathrm{~A})$ & $\operatorname{tet}(\mathrm{L})$ & $\operatorname{tet}(\mathrm{M})$ & $\operatorname{tet}(\mathrm{K})$ & int & DA, FOX, TGC, TE, QD \\
\hline 20 S. aureus & salads & $m e c(\mathrm{~A})$ & $\operatorname{tet}(\mathrm{L})$ & $\operatorname{tet}(\mathrm{M})$ & - & - & FOX \\
\hline 21 S. aureus & salads & $m e c(\mathrm{~A})$ & $\operatorname{tet}(\mathrm{L})$ & $\operatorname{tet}(\mathrm{M})$ & - & - & DA, FOX, TGC, CIP \\
\hline 22 S. aureus & salads & $m e c(\mathrm{~A})$ & $\operatorname{tet}(\mathrm{L})$ & $\operatorname{tet}(\mathrm{M})$ & - & int & DA, FOX, TGC, TE,QD \\
\hline 23 S. aureus & salads & $m e c(\mathrm{~A})$ & $\operatorname{tet}(\mathrm{L})$ & $\operatorname{tet}(\mathrm{M})$ & - & int & FOX, F, W, TGC, TE, SXT \\
\hline 24 S. aureus & salads & $m e c(\mathrm{~A})$ & - & - & - & - & FOX, F, CN \\
\hline 25 S. aureus & salads & $m e c(\mathrm{~A})$ & - & - & - & - & DA, FOX, F, CN \\
\hline 26 S. aureus & salads & $m e c(\mathrm{~A})$ & - & - & - & - & DA, FOX, F, TGC \\
\hline 27 S. aureus & salads & $m e c(\mathrm{~A})$ & $\operatorname{tet}(\mathrm{L})$ & $\operatorname{tet}(\mathrm{M})$ & - & int & DA, FOX, LZD, QD \\
\hline 28 S. aureus & hamburger & $m e c(\mathrm{~A})$ & - & - & - & - & DA, FOX \\
\hline 29 S. aureus & hamburger & $m e c(\mathrm{~A})$ & - & - & - & - & DA, FOX \\
\hline $30 \quad$ S. aureus & hamburger & $m e c(\mathrm{~A})$ & - & - & - & - & E, DA \\
\hline 31 S. aureus & hamburger & $m e c(\mathrm{~A})$ & - & - & - & - & FOX, W, TGC, SXT, RD \\
\hline S. aureus & hamburger & $m e c(\mathrm{~A})$ & $\operatorname{tet}(\mathrm{L})$ & $\operatorname{tet}(\mathrm{M})$ & - & int & DA, FOX, TGC,TE, RD, CN, LZD \\
\hline
\end{tabular}

Abbreviations: E - erythromycin, DA - clindamycin, CN - gentamicin, FOX -cefoxitin, TE - tetracycline, TGC - tigecycline, RD - rifampicin, F - nitrofurantoin, LZD - linezolid, W - trimethoprim, QD - quinupristin/dalfopristin, SXT trimethoprim/sulfametoxasol

Source: Authors

Genotyping analysis indicated that all of the isolates phenotypic resistant to tetracycline harbored at least one tetracycline resistance determinant on which $\operatorname{tet}(\mathrm{M})$ was most frequent. The $\operatorname{tet}(\mathrm{L}) \operatorname{genes} \operatorname{did}$ also appear but were less common. Gene $\operatorname{tet}(\mathrm{K})$ was always associated with $\operatorname{tet}(\mathrm{M})$ and $\operatorname{tet}(\mathrm{L})$. All of the isolates positive for tet $(\mathrm{M})$ genes were positive for the Tn916/Tn1545-like integrase family gene. All of the cefoxitin resistant strains harbored mecA gene. Most MRSA strains were resistant to at least three of the antibiotics tested, and 25 of 28 MRSA strains were classified as MDR.

In other recently reported studies, lower isolation frequencies for MRSA in foods were found. In an Italian survey of $160 \mathrm{~S}$. aureus strains analyzed six strains $(3.75 \%)$ harbored the mecA gene. In Japan, Hammad et al. (2012) examined 200 samples of retail ready-to-eat raw fish (sashimi) of which they recovered $10 \mathrm{MRSA} / \mathrm{MR}-\mathrm{CoNS}$ isolated from 10 different samples (5\%, 10/200). In our previous study we have examined 858 samples of RTE food (including cheeses, cured meats, sausages, smoked fishes) on which $6 \%$ of isolated strains were positive for mecA (35 MRSA and 17 MR-CoNS strains) (Chajęcka-Wierzchowska et al., 2014). Like as in these studies all MRSA strains carry mecA gene, in contrast to results published by other authors (Hammad et al., 2012; Lee et al., 2004)

Most of the studies on antibiotic resistance in $S$. aureus have concentrated on strains isolated from clinical samples. Recently, some researchers have suggested that environment and food could play a significant role in the transmission of resistance to humans (Wang et al., 2012; Chajęcka- 
Wierzchowska et al., 2014, 2015). Furthermore, Gram-positive bacteria acquire and transfer resistance to antibiotics much more often and more easily than Gram-negative bacteria. The results obtained indicate the need for food monitoring for the presence of antibiotic-resistant $S$. aureus and the possibility of transferring and transmitting antibiotic resistance genes. S. aureus strains present in ready-to-eat food can pose a hazard for consumer health serving as a reservoir of resistance genes.

\section{Conclusions}

Our data indicate that $S$. aureus is widely present in retail sushi, but also hamburgers and salads. Many isolated strains are antibiotic resistant and carry transferable genes which represent a potential source of resistance transmission to bacteria in humans. The most disturbing fact is that most $S$. aureus strains were resistant to methicillin and had mecA gene. Our results indicated that retail RTE food could be considered as important route for transmission of antibiotic resistant staphylococci harboring multiple antibiotic resistance genes.

\section{References}

Andrighetto C., Knijff E., Lombardi A., Torriani S., Vancanneyt M., Kersters K., Swings J., Dellaglio F. (2001) Phenotypic and genetic diversity of enterococci isolated from Italian cheeses. Journal of Dairy Research, 68, 2, 303-316.

Barski P., Piechowicz L., Galiński J., Kur J. (1996). Rapid assay for detection of methicillin-resistant Staphylococcus aureus using multiplex PCR. Molecular and Cellular Probes, 10, 471-475

Chajęcka-Wierzchowska W., Zadernowska A. (2016). Antibiotic resistance of coagulase-positive and coagulase-negative staphylococci isolated from food, chapter in book "Foodborne Pathogens and Antibiotic Resistance", (ISBN: 978-1-11913915-7), edited by Om V. Singh,Wiley-Blackwell, 2016

Chajęcka-Wierzchowska W., Zadernowska A., Nalepa B., Sierpińska M., Łaniewska-Trokenheim Ł. (2015). Coagulasenegative staphylococci (CoNS) isolated from ready-to-eat food of animal origin--phenotypic and genotypic antibiotic resistance, Food Microbiology, 46, 222-226.

Chajęcka-Wierzchowska W., Zadernowska A., Nalepa B., Sierpińska M., Łaniewska-Trokenheim Ł. (2014). Retail ready-toeat (RTE) food as a potential vehicle for Staphylococcus spp. Journal of Food Protection, 77 (6), 993-998.

Ding C., He. J. (2010). Effect of antibiotics in the environment on microbial populations. Applied Microbiology and Biotechnology, 87, 925-941.

Gevers D., Huys G., Swings J. (2003). In vitro conjugal transfer of tetracycline resistance from Lactobacillus isolates to other Gram-positive bacteria. FEMS Microbiology Letters, 225, 125-130.

Hageman J.C., Uyeki T.M., Francis J.S., Jernigan D.B., Wheeler J.G., Bridges C.B., Barenkamp S.J., Sievert D.M., Srinivasan A., Doherty M.C. (2006). Severe community-acquired pneumonia due to Staphylococcus aureus, 2003-04 influenza season. Emerging Infectious Diseases. 12, 894-899.

Hammad A.M., Hammad T., Fujii, Watanabe W., Shimamoto T. (2012). Occurrence and characteristics of methicillinresistant and -susceptible Staphylococcus aureus and methicillin-resistant coagulase-negative staphylococci from Japanese retail ready-to-eat raw fish. International Journal of Food Microbiology, 156, 286-289.

Hennekinne, J.A. De Buyser, M.L. Dragacci S. (2012). Staphylococcus aureus and its food poisoning toxins: characterization and outbreak investigation. FEMS Microbiology Reviews, 36, 815-836.

Le Loir Y., Baron F., Gautier M. (2003). Staphylococcus aureus and food poisoning. Genetic and Molecular Research, 2, $63-76$.

Lee J.H., Jeong J.M., Park Y.H., Choi S.S., Kim Y.H., Chae J.S., Moon J.S., Park H., Kim S., Eo S.K. (2004). Evaluation of the methicillin-resistant Staphylococcus aureus (MRSA)-Screen latex agglutination test for detection of MRSA of animal origin. Journal of Clinical Microbiology, 42, 2780-2782.

Lina G., Piémont Y., Godail-Gamot F., Bes M., Peter M.O., Gauduchon V., Vandenesch F., Etienne J. (1999). Involvement of panton-valentine leukocidin-Producing Staphylococcus aureus in primary skin infections and pneumonia. Genetic and Molecular Research, 29, 1128-1132.

Macovei L., Zurek L. (2006). Ecology of antibiotic resistance genes: characterization of enterococci from houseflies collected in food settings. Applied and Environmental Microbiology, 72, 4028-4035.

Morot-Bizot S, Talon R, Leroy S. (2004). Development of a multiplex PCR for the identification of Staphylococcus genus and four staphylococcal species isolated from food. Journal of Applied Microbiology. 97, 1087-94.

Normanno G., Corrente M., La Salandra G., Dambrosio A., Quaglia N.C., Parisi A., Greco G., Bellacicco A.L., Virgilio S., Celano G.V. ( 2007). Methicillin-resistant Staphylococcus aureus (MRSA) in foods of animal origin product in Italy. International Journal of Food Microbiology, 117,219-222.

Oniciuc E.A., Nicolau A. I., Hernández M., Lázaro D. R. (2017). Presence of methicillin-resistant Staphylococcus aureus in the food chain. Trends in Food Science \& Technology, 61, 49-59.

Rizzotti L., La Gioia F., Dellaglio F., Torriani S. (2009). Characterization of tetracycline-resistant Streptococcus thermophilus isolates from Italian soft cheeses. Applied and Environmental Microbiology, 75(12), 4224-4229.

Wang H., McEntire J.C., Zhang L., Li X., Doyle M. (2012). The transfer of antibiotic resistance from food to humans: facts, implications and future directions. Scientific and Technical Review. 31,1, 249-60. 